PERM JOURNAL OF PETROLEUM AND MINING ENGINEERING

ВЕСТНИК ПНИПУ. ГЕОЛОГИЯ. НЕФТЕГАЗОВОЕ И ГОРНОЕ ДЕ

ISSN 2224-9923

Volume/ ToM 17 №2 2018

http://vestnik.pstu.ru/geo/

УДК 622.276:543.429.23

Article / Статья

(C) PNRPU / ПНИПУ, 2018

\title{
APPLICATION OF NUCLEAR MAGNETIC RESONANCE TO STUDY BITUMINOUS OIL IN THE SOUTH WESTERN NIGERIA
}

\section{Leyii K. Nwizug-Bee, Olga V. Savenok, Yuriy N. Moysa ${ }^{1}$}

Kuban State Technological University (2 Moskovskaya st., Krasnodar, 350072, Russian Federation)

${ }^{1}$ NPO Khimburneft LLC (7 Kubanskaya Naberezhnaya, Krasnodar, Russian Federation, 350063)

\section{ПРИМЕНЕНИЕ ЯДЕРНО-МАГНИТНОГО РЕЗОНАНСА ДЛЯ ИЗУЧЕНИЯ БИТУМИНОЗНОЙ НЕФТИ НА ЮГО-ЗАПАДЕ НИГЕРИИ}

\section{Л.К. Нвизуг-Би, О.В. Савенок, Ю.Н. Мойса'}

Кубанский государственный технологический университет (350072, Россия, г. Краснодар, ул. Московская, 2)

${ }^{1} \mathrm{OOO}$ «НПО “Химбурнефть”» (350063, Россия, г. Краснодар, ул. Кубанская набережная, 7)

Received / Получена: 21.01.2018. Accepted / Принята: 09.06.2018. Published / Опубликована: 29.06.2018

Key words:

nuclear magnetic resonance method, tetramethylsilane, spectrum, absorption, oxygen, hydrogen, core, nuclei, proton, resources, bitumen, oil, spectroscopy.

\begin{abstract}
Heavy bituminous oil is the main source of Nigerian unconventional resources. The resources represent oil sand and bitumen oil forming a belt of bitumen oil covering about $120 \mathrm{~km}$ extending from Lagos, Ogun, Ondo and Edo. Huge reserves of the resources are located in the state of Ondo. A nuclear magnetic resonance (NMR) method was used in the research to study bitumen oil in South West Nigeria. The NMR spectroscopy on the nuclei of ${ }^{1} \mathrm{H}$ and ${ }^{13} \mathrm{C}$ uses signals from protons and carbon nuclei, respectively, tetramethylsilane molecules $\mathrm{Si}\left(\mathrm{CH}_{3}\right)_{4}$. Regions of absorption of aliphatic $(7-65 \mathrm{ppm})$ and aromatic $(108-170 \mathrm{ppm})$ nuclei of carbon atoms are clearly defined in the NMR spectra of $13 \mathrm{C}$ of the objects under consideration. Signals of carbon atoms of olefinic fragments make a significant contribution to the last range of spectra of the cores of Nigerian bitumen deposits. An analysis of more known methods of defining the aromatic region of the nuclear magnetic resonance spectrum of $13 \mathrm{C}$ showed that for fractions that do not contain condensed cyclic and heteroatomic compounds, the definition of chemical shift subranges (CS) corresponding to aromatic carbon atoms 110-130 ppm not substituted, 130-137 ppm substituted by methyl, another alkyl - and naphthyl substituted - 137-148 ppm is sufficienly reasonable. There are regions of absorption of quaternary carbon atoms bonded to oxygen or nitrogen $(148-170 \mathrm{ppm})$, carbonyl carbon atoms $(170-200 \mathrm{ppm})$, as well as tertiary aromatic carbon atoms, located in the ortho position to the hydroxyl or other oxygen atom $(108-118 \mathrm{ppm})$ in objects containing larger amounts of heteroatoms.
\end{abstract}

Ключевые слова: метод ядерно-магнитного резонанса, тетраметилсилан, спектр, поглощение, кислород, водород, керн, ядра, протон, ресурсы, битум, нефть, спектроскопия.
Тяжелая битуминозная нефть является основным источником нигерийских нетрадиционных ресурсов. Эти ресурсы существуют в виде нефтеносного песка и битуминозного масла, образуя пояс битумной нефти, охватывающий около 120 км, простирающийся от Лагоса, Огун, Ондо и Эдо, причём огромные запасы этих ресурсов находятся в штате Ондо. В этом исследовании применен метод ядерно-магнитного резонанса (ЯМР) для изучения битуминозной нефти юго-запада Нигерии. В спектроскопии ЯМР на ядрах ${ }^{1} \mathrm{H}$ и ${ }^{13} \mathrm{C}$ в качестве стандарта используют сигналы протонов и ядер углерода, соответственно, молекулы тетраметилсилана $\mathrm{Si}\left(\mathrm{CH}_{3}\right)_{4}$. В спектрах ЯМР ${ }^{13} \mathrm{C}$ рассматриваемых объектов разделяются полностью области поглощения алифатических (7-65 м.д.) и ароматических (108-170 м.д.) ядер атомов углерода. В спектрах керна битуминозных отложений Нигерии в последний диапазон вносят заметный вклад сигналы атомов углерода олефиновых фрагментов. Анализ более известных способов дробного деления ароматической области спектра ядерно-магнитного резонанса ${ }^{13} \mathrm{C}$ показал, что для фракций, не содержащих конденсированных циклических и гетероатомных соединений, достаточно обоснованным можно признать выделение поддиапазонов химического сдвига, соответствующих ароматическим атомам углерода: незамещенным - 110-130 м.д., метилзамещенным - 130-137 м.д., другим алкили нафтилзамещенным - 137-148 м.д. В объектах, содержащих более значительные количества гетероатомов, выделяют области поглощения четвертичных атомов углерода, связанных с кислородом или азотом, $-148-170$ м.д., карбонильных углеродных атомов - 170-200 м.д., а также третичных ароматических атомов углерода, находящихся в орто-положении к гидроксильному или эфирному атому кислорода, $-108-118$ м.д.

Leyii K. Nwizug-Bee - PhD student (tel.: +007 91833951 82, e-mail: kluivert_dgreat@mail.ru). The contact person for correspondence.

Olga V. Savenok - Doctor of Engineering, Professor at the Depatment of Oil and Gas named after professor G.T. Vartumyan (tel.: +007 918 32661 00, e-mail: olgasavenok@mail.ru)

Yuriy N. Moysa - PhD in Chemistry (tel.: +007 988246 19 28, e-mail: HBN2005@yandex.ru).

Нвизуг-Би Лейи Клюверт - аспирант (тел.: +007 91833951 82, e-mail: kluivert dgreat@mail.ru). Контактное лицо для переписки.

Савенок Ольга Вадимовна - доктор технических наук, профессор кафедры нефтегазового дела имени профессора Г.Т. Вартумяна (тел.: +007 9183266100 , e-mail: olgasavenok@mail.ru).

Мойса Юрий Николаевич - кандидат химических наук (тел.: +007 988246 19 28, e-mail: HBN2005@yandex.ru) 


\section{Introduction}

According to the definition of the United Nations Institute for Training and Research the word "bitumen" means a hydrocarbon that is essentially immobile in a formation. Heavy oil may differ from bitumen by about $20^{\circ}$ API. Within this range heavy oil is sometimes subdivided into super heavy and heavy at the density of $10^{\circ}$ API [1-4].

Reservoir temperature plays a very important role in determining the viscosity of oil or its mobility. The Fig. 1 shows the rating of 10 countries that have reserves of bitumen and extra heavy oil. Classification of hydrocarbons in reservoir conditions is often used in the regulation of hydrocarbon reserves. Bitumen is most often regulated in accordance with the national rules for the extraction of minerals. Light oil is regulated in accordance with national regulations for hydrocarbons or oil [5-15].

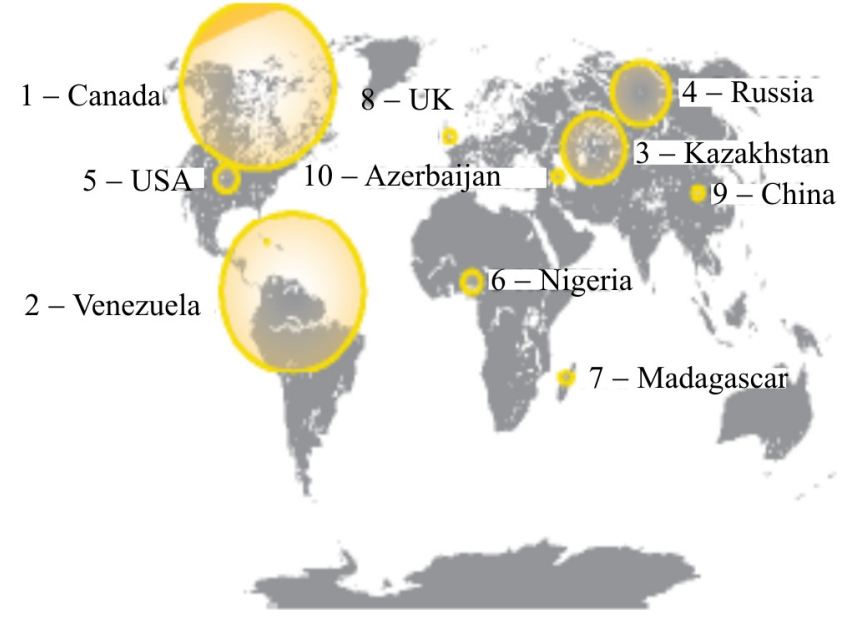

Fig. 1. Rating of 10 countries that have reserves of bitumen and extra heavy oil [17]

\section{Regional geological formulation: structure and tectonics}

Bituminous sandstones in southwestern Nigeria are located between the coastal plain and elevation. Geological conditions are characterized by the resins of Ilesha province, structural and minor topographic abysses. Plains and highlands of Benin basin are in the west, valley and delta of the Niger are in the east where shallow layers of the Anambra basin are studied.

The coastal plain is underlain by sedimentary strata forms surface of the earth, usually with a low relief. Drainage is moderately integrated, but most of the rivers are relatively small and have drainage basins either in the coastal plain or in adjacent hills. Most of the land surface has a good developed lateritic soil cover. Bedrocks are usually not affected, except for artificial sections or excavations. Sandstones and clays of Cretaceous and Tertiary age lie in the northern part of the coastal plain; some of them are relatively unconsolidated. The southern part of the coastal plain represents a coastal lowland strip, slightly widening to the east, where swamp and coastline relief are dominating. Alluvial valleys sediments of Quaternary age have a border with larger rivers [16-20].

Resins compose the area of higher relief to the north. Gneisses, quartzites, granites and shales dominate in the set of igneous and metamorphic rocks of Precambrian age. Sedimentary sequences on hills of the basement indicate in several places a tendency to overlap the formations with the underlying surface when it rises to the north. In the south deposits are located in a sedimentary chain at great depths.

The Benin basin is named after a country that borders Nigeria in the west. It was called Dahomey and Cotonou basin. The basin was formed after the rifts in a marginal position. That developed in the shallow gulf of the coast of West Africa after the opening of the equatorial Atlantic Ocean in the early Cretaceous period. The Benin basin is extended east-west parallel to the coastline, extending from Ilesha's spur in the east to the coastal lowlands of Ghana in the west. The northern edge of the basin is characterized by the exposure of the basement, which is located $130 \mathrm{~km}$ from the coast along the central axis of the basin near the border of Nigeria and Benin. The southern limit of the basin is poorly defined and is located beneath the seabed beyond the continental shelf.

The Anambra basin, east side of oil sandstones, is the geological area that lies at the base of the western coastal part of the Niger Delta. Like the basin of Benin, it originated in the early Cretaceous period as a rift structure and is distinguished by its extension to the north-east as one of a series of structural deflections caused by the thinning of the crust along the failed axis of the rift perpendicular to the center of the Atlantic. Benin hinge represents the most significant part of this system. It is a clearly defined structure located north-east, where the northwestern flank of the basin meets the spine of Ilesha [21-24]. 


\section{Stratigraphy}

The age of formations of the eastern Benin basin and the Ilesha spur is from Cretaceous to modern. Surface distributions of major lithostratigraphic units were mapped across the region, resulting in a basic stratigraphic structure that uses surface survey data and information about shallow wells. Some stratigraphic nomenclatures can be used, while others are based on descriptions of outcrops.

Sandstones and shales of Maastrichtian (late Cretaceous) age exposed in the resin belt are the oldest layers. These fossils usually denote the formation of Aboeokuta. In its typical location to the west of the resin belt, the Abeokuta form has a thickness of approximately 600 feet, but it becomes somewhat thinner in the east. Detailed studies of the resin belt show that individual sandstones are strong, but the general picture consists of basal sandstones and conglomerates, followed by a sandy-shale gap of several hundred feet and then the upper part of shales [25-29].

\section{Magnetic properties of the core}

The nuclei have a spin quantum number I (nuclear spin). The phenomenon of nuclear magnetic resonance (NMR) can be observed only for nuclei with a nonzero spin quantum number, $\mathrm{I} \neq 0$. Nuclei with $\mathrm{I} \neq 0$ have a magnetic quantum number $m_{i}=\mathrm{I}, \mathrm{I}-1, \mathrm{I}-2, \ldots-\mathrm{I}$ (values range from $\mathrm{I}$ to $-\mathrm{I}$, through 1). For the nucleus of the hydrogen atom ${ }^{1} \mathrm{H}$ (proton): $\mathrm{I}=1 / 2$ and $m_{i}=1 / 2,-1 / 2$. The nuclei of atoms have their own angular momentum

$$
p=\sqrt{\mathrm{I}(\mathrm{I}+1)} h / 2 \pi,
$$

where I - nuclear spin, $h$ - Planck's constant. Magnetic nuclei $(I \neq 0)$ are characterized by a magnetic moment $\mu$, which is calculated by the formula $\mu=\gamma \cdot p, m_{i}$ - projection of the vector $\mu$ on the magnetic field strength line; $\gamma$ - gyromagnetic ratio (individual characteristic of the nucleus).

The energy of the nucleus in a magnetic field is characterized by the expression

$$
E=-m h / 2 \pi \gamma \beta_{0},
$$

where $\beta_{\mathrm{o}}$ - magnetic field strength. For $m_{1}=+1 / 2$, $E_{1}=-h / 4 \pi \gamma \beta_{0}$. For $m_{2}=-1 / 2, E_{2}=h / 4 \pi \gamma \beta_{0}$. $\Delta E=E_{2}-E_{1}=h / 2 \pi \gamma \beta_{0}$. The basic NMR equation is described by the expressions

$$
\Delta E=h / 2 \pi \gamma \beta_{\mathrm{o}}, \Delta E=h v,
$$

where $h$ - Planck's constant, $\gamma-$ gyromagnetic ratio; $\beta_{\mathrm{o}}$ - magnetic field strength, $v$ - resonant frequency, $v=\gamma \beta_{\mathrm{o}} / 2 \pi$. For nuclei ${ }^{1} \mathrm{H} \gamma=2.674 \times$ $\times 10^{8} \mathrm{c}^{-1} \mathrm{Tl}^{-1}$ at $\beta_{\mathrm{o}}=1.4 \mathrm{Tl}, v=60 \mathrm{MHz}$ (resonance) [30-39].

\section{Objects and methods of research}

The Yegbata core from the south-west of Nigeria was selected from the depth of $750 \mathrm{~m}$. The electronic image of the surface of the bituminous core sample is obtained using the high-resolution scanning microscope JSM 7500F (Japan) with a resolution of $1 \mathrm{~nm}$ at 100-fold zoom and is shown in Fig. 2.

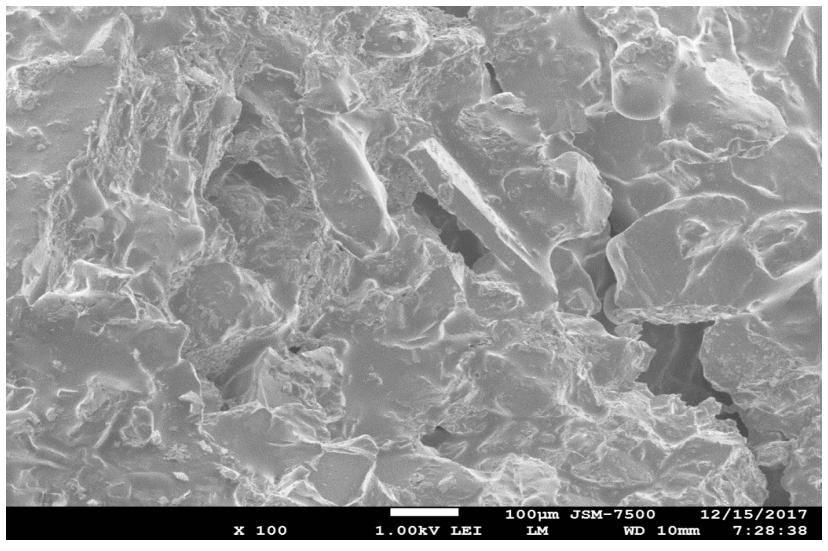

Fig. 2. Electronic surface image of bituminous core of the Yegbata deposit, Nigeria

The NMR spectra were recorded on the JNM ECA-400 spectrometer (Japan, JEOL, $400 \mathrm{MHz}$ ) in deuterated chloroform. As an internal standard, tetramethylsilane was used. A sample of a part of the bituminous core (sampling depth of $750 \mathrm{~m}$ ) was placed in a solvent and mixed until the organic phase. Insoluble residue of the rock was filtered out. Number of accumulations for the spectrum for ${ }^{1} \mathrm{H}$ is 48 , for ${ }^{13} \mathrm{C}$ is 5000 .

There is in the spectrum ${ }^{1} \mathrm{H}$ the signal of the solvent is at $7.21 \mathrm{ppm}$, the signal of the standard is at $0 \mathrm{ppm}$. The spectrum contains signals from groups $\mathrm{CH}_{3}$ with a shift of $1 \mathrm{ppm}$, for $\mathrm{CH}_{2}$ shift is $1,5 \mathrm{ppm}$ and signals branched alkyl fragments in the shear region $(2.2 \mathrm{ppm})$. The shift signal in the region of 7-8 ppm corresponds to hydrogen signals of aromatic groups. The ${ }^{1} \mathrm{H}$ NMR spectrum of the organic part of the bituminous core sample shows a peak value at a chemical shift of 1.5 ppm (Fig. 3). 


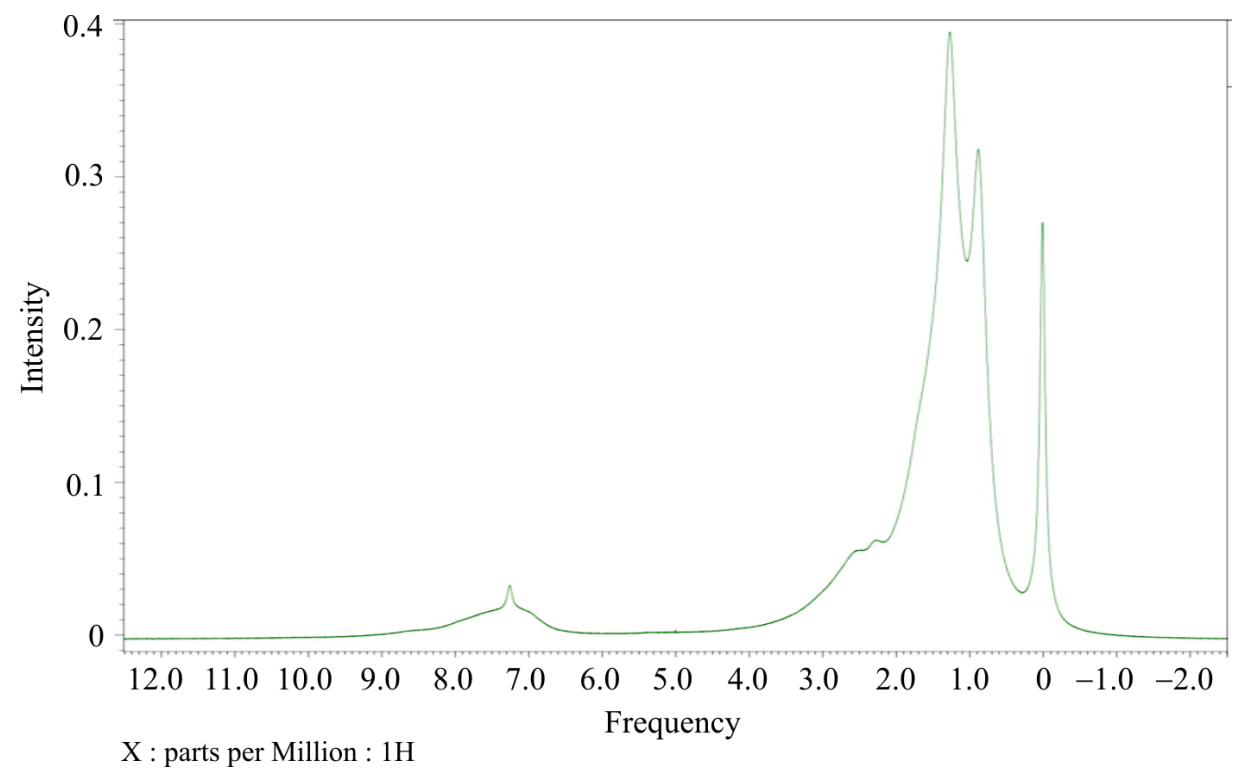

Fig. 3. Nuclear Magnetic Resonance Spectrum of 1N Bituminous Oil of Nigeria
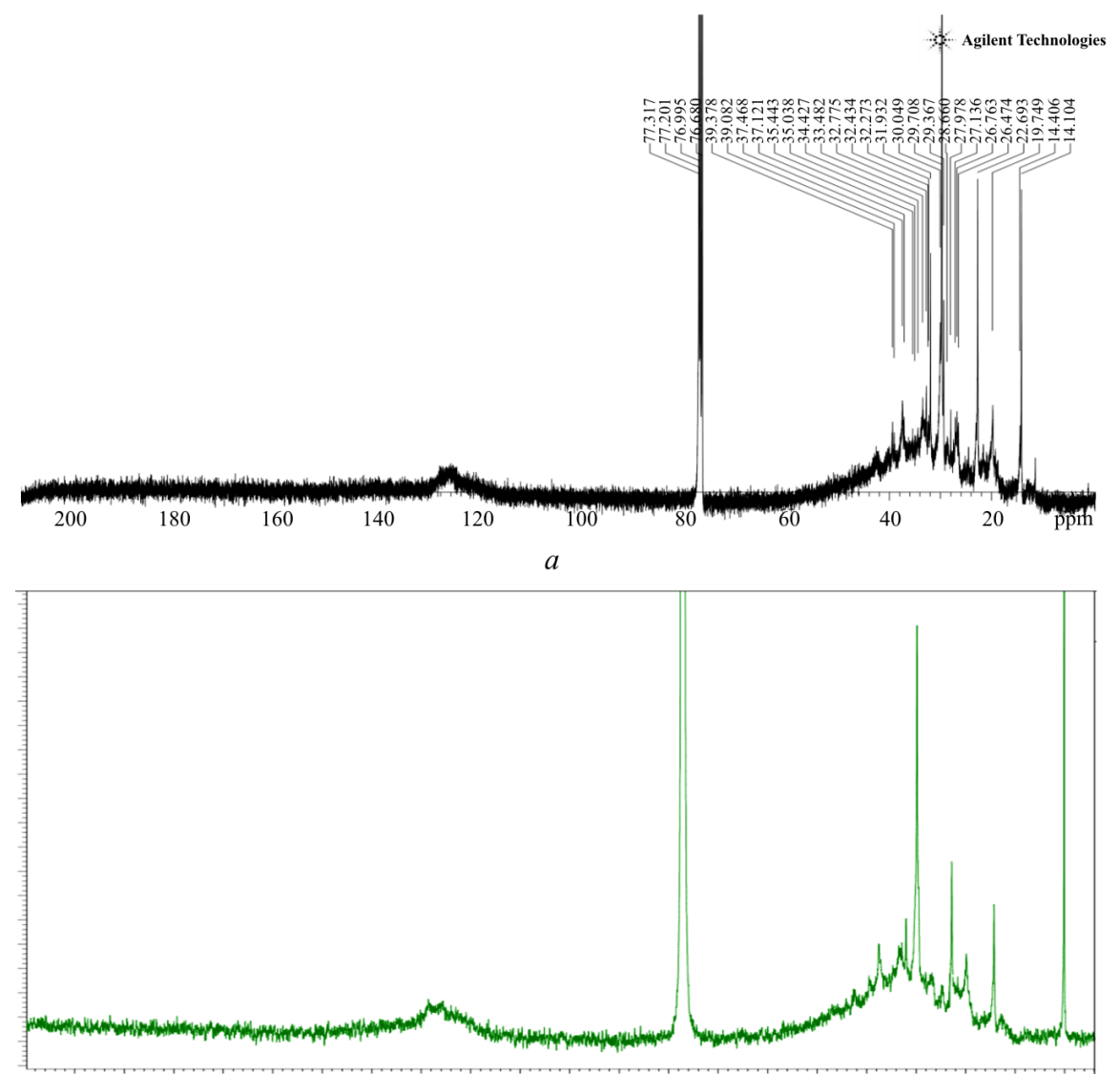

$200.0190 .0170 .0160 .0150 .0140 .0130 .0120 .0110 .0100 .090 .0 \quad 80.0 \quad 70.0 \quad 60.050 .0 \quad 40.0 \quad 30.020 .0 \quad 10.0 \quad 0.0$

$b$

Fig. 4. Nuclear Magnetic Resonance Spectrum of ${ }^{13} \mathrm{C}: a-$ Kuban oil; $b$ - bituminous oil field of Yegbata in Nigeria

The ${ }^{13} \mathrm{C}$ spectrum shows the intense signal of the solvent at $77 \mathrm{ppm}$ and TMS standard signal at $0 \mathrm{ppm}$. There are signals observed in the spectrum of the carbon nuclei of various alkyl groups (saturated hydrocarbons) $\mathrm{CH}_{3}, \mathrm{CH}_{2}$ and $\mathrm{CH}$ in the region of shifts from 10 to $50 \mathrm{ppm}$. A large group of signals in the region of $130 \mathrm{ppm}$ corresponds to carbon signals of aromatic groups 
of polycyclic compounds of bituminous oil. The general form of the ${ }^{13} \mathrm{C}$ NMR spectrum indicates a large number of aliphatic and aromatic components of bituminous oil.

\section{Results and discussion}

For a comparative illustration the NMR spectrum of ${ }^{13} \mathrm{C}$ of the Kuban oil of the Western Akhtanizovsky deposit (well No. 30, bottom 1479 $\mathrm{m})$ is shown in Fig. $4 a$. There is the ${ }^{13} \mathrm{C}$ NMR spectrum of bituminous oil from Nigeria of the Yegbata deposit shown in Fig. $4 b$.
There is a coincidence of the NMR ${ }^{13} \mathrm{C}$ spectra of the Kuban oil and bituminous oil of Nigeria determined in the region of signals of the ${ }^{13} \mathrm{C}$ carbon nuclei of aliphatic groups of the compared spectra (see Fig. 4). However, there are more wide intense lines in the aromatic carbons area in the range of $108-150$ ppm observed in the ${ }^{13} \mathrm{C}$ NMR spectrum of the bitumen oil sample of Nigeria.

The range of chemical shifts of ${ }^{13} \mathrm{C}$ NMR and assignment of carbon classes for a sample of bituminous oil from the Yegbata deposit in Nigeria are shown in the table.

Range ${ }^{13} \mathrm{C}$ and classes of carbon of the bitumen sample from the Yegbata field of Nigeria

\begin{tabular}{|c|c|l|}
\hline $\begin{array}{c}\text { The range of chemical } \\
\text { shifts of }{ }^{13} \mathrm{C}, \mathrm{ppm}\end{array}$ & $\begin{array}{c}\text { Identification } \\
\text { of carbon classes }\end{array}$ & \multicolumn{1}{|c|}{ Classification of carbon } \\
\hline $0-107$ & $\mathrm{C}_{\mathrm{al}}$ & Aliphatic carbon atoms \\
\hline $108-118$ & $\mathrm{C}_{\mathrm{ar} . \mathrm{op}}$ & Tertiary aromatic carbon atoms in ortho-position to ethereal oxygen \\
\hline $110-130$ & $\mathrm{C}_{\mathrm{ar}}$ & Tertiary aromatic carbon atoms* \\
\hline $130-137$ & $\mathrm{C}_{\mathrm{ar} . \mathrm{m}}$ & Methyl-substituted aromatic carbon atoms* \\
\hline $137-148$ & $\mathrm{C}_{\mathrm{ar} . \mathrm{al}-\mathrm{nap}}$ & Alkyl- and naphthyl-substituted aromatic carbon atoms* \\
\hline $148-170$ & $\mathrm{C}_{\mathrm{ar}} \mathrm{O}$ & Aromatic carbon atoms substituted by a phenolic or ester group \\
\hline $170-200$ & $\mathrm{C}_{\mathrm{c}}$ & Carbonyl carbon atoms \\
\hline
\end{tabular}

Note: ${ }^{*}$ - absence of heteroatomic and condensed aromatic compounds.

\section{Conclusion}

Core samples of bituminous deposits of the Yegbata field of Nigeria are studied using the modern methods of spectral studies. The classes of hydrocarbons that make up the organic part of the core of the bituminous field of Nigeria are determined. The coincidence of the ${ }^{13} \mathrm{C}$ spectra of the Kuban oil and NMR ${ }^{13} \mathrm{C}$ spectra of bituminous oil in Nigeria in the area of chemical shifts of the ${ }^{13} \mathrm{C}$ carbon nuclei of aliphatic groups (saturated hydrocarbons) $\mathrm{CH}_{3}, \mathrm{CH}_{2}$ and $\mathrm{CH}$ in the shift range from 10 to $50 \mathrm{ppm}$ is shown. The ${ }^{13} \mathrm{C}$ NMR spectrum of the bituminous oil sample has a wider range and larger integral value in the region of $118-150 \mathrm{ppm}$, which corresponds to carbon signals of aromatic groups of polycyclic compounds of bituminous oil in Nigeria. The ${ }^{1} \mathrm{H}$ NMR spectrum of the sample of the organic core component shows an increased peak value with a chemical shift of $1.5 \mathrm{ppm}$ aliphatic part of the bituminous oil of Nigeria. The spectral data of organic part of the real core material obtained indicate a unique source of raw materials with a wide component composition of aliphatic and aromatic hydrocarbons included in the bituminous oil of the Yegbata field in Nigeria.

\section{References}

1. Abdulkhanrov R.M., Akhnurov R.M., Gareev R.M. et al. Sovershenstvovanie sistemy razrabotki mestorozhdenii prirodnogo bituma [Improvement of the system of development of natural bitumen deposits]. Povyshenie nefteotdachi plastov na pozdnei stadii razrabotki neftianykh mestorozhdenii i kompleksnoe osvoenie vysokoviazkikh neftei $i$ prirodnykh bitumov. Materialy mezhdunarodnoi nauchnoprakticheskoi konferentsii, 2007, pp.227-234.

2. Abramzon A.A. Poverkhnostno-aktivnye veshchestva: svoistva i primenenie [Surfactants: properties and applications]. Leningrad, Khimiya, 1981, 303 p.

3. Antoniadi D.G. Nauchnye osnovy razrabotki mestorozhdenii termicheskimi metodami [Scientific bases of field development by thermal methods]. Moscow, Nedra, 1995, 313 p.
4. Antoniadi D.G., Valuiskii A.A., Garushev A.R. Sostoianie dobychi nefti metodami povysheniia nefteizvlecheniia $\mathrm{v}$ obshchem obeme mirovoi dobychi [The state of oil extraction by methods of increasing the oil extraction in the total volume of world production]. Oil industry, 1999, no.1, pp.16-23.

5. Adegoke O.S., Omotsola M., Coker S. The geology of the Nigerian tar sands. 5th UNITAR Conference. Caracas, 1991, pp.369-385.

6. Adelu R., Fayose E. Development prospects for the bituminous deposits in Nigeria. 5th UNITAR Conference. Caracas, 1991, pp.509-515.

7. Ademodi B., Dewodu O., Oshonowo T. et al. Recovery of bitumen from Nigerian tar sands - feed preparation and solvent extraction studies. $7^{\text {th }}$ Miami 
International Conference on Alternative Energy Sources, Miami, 1985, p.2.

8. Adewusi V.A. Aspect of tar sands development in Nigeria. Energy Sources, 1992, vol.14, pp.305-315. DOI: $10.1080 / 00908319208908728$.

9. Adesida A. Geology of the ore tar sands (maastrichtian - paleocene): MSc. Thesis, University of Ife. Ife, 1980, p.121.

10. Akhunov R.M., Abdulkhairov R.M., Gareev R.Z. et al. Sposob povysheniya effektivnoy dobychi prirodnykh bitumov [A way to increase the effective production of natural bitumen]. Tekhnika i dobychi nefti, 2007, no.8, pp.132-134.

11. Lipaev A.A. Razrabotka mestorozhdenii tiazhelykh i prirodnykh bitumov [Development of deposits of heavy and natural bitumen]. Moscow, Izhevsk, Institut kompiuternykh issledovanii, 2013, $484 \mathrm{p}$.

12. RD 39-0147001-742-92. Metodika kompleksnoi otsenki kachestva vskrytiia produktivnykh plastov, zakanchivaniia skvazhin i vybora rabochikh zhidkostei dlia povysheniia kachestva vskrytiia plastov [Methodology of complex estimation of the quality of opening of productive layers, completion of wells and the choice of working fluids for improving the level of opening of layers]. Krasnodar, Rossiiskaia gosudarstvennaia neftegazovaia korporatsiia VNIIKRneft, 1992, 82 p.

13. Muslimov R.Kh., Musin M.M., Musin K.M. Opyt primeneniia teplovykh metodov razrabotki na neftianykh mestorozhdeniiakh Tatarstana [Experience in the application of thermal methods of development at the oil fields of Tatarstan]. Kazan, Novoe znanie, 2000, 225 p.

14. Ruzin L.M., Chuprov I.F., Morozyuk O.A. et al. Tekhnologicheskie printsipy razrabotki zalezhei anomalno viazkikh neftei i bitumov [Technological principles for the development of deposits of abnormal viscous oils and bitumen]. Moscow, Izhevsk, Institut kompiuternykh issledovanii, 2015, $476 \mathrm{p}$.

15. Iakovenko V.I., Moisa N.Iu., Ovsiannikov P.P. et al. Apriornaia otsenka kachestva vskrytiia plasta po dannym eksperimentalnykh issledovanii na naturnykh kernakh [A priori assessment of the level of autopsy by experimental studies on natural cores]. Stroitelstvo neftianykh i gazovykh skvazhin na sushe i na more, 2010, no.2, pp.50-51.

16. Nvizug-Bi L.K., Savenok O.V., Moisa Iu.N. Klassifikatsiia trudnoizvlekaemykh zapasov na territorii Federativnoi Respubliki Nigerii [Classification of hard-torecover reserves in the territory of the Federal Republic of Nigeria]. Nauka, tekhnika $i$ tekhnologiia, 2015, vol.11 (17), no.2, pp.18-21.

17. Nvizug-Bi L.K., Savenok O.V. Trudnoizvlekaemye zapasy uglevodorodov vazhnye resursy na territorii Federativnoi Respubliki Nigerii [Hard-to-recover hydrocarbon reserves, important resources in the territory of the Federal Republic of Nigeria]. Sovremennoe sostoianie estestvennykh i tekhnicheskikh nauk. Materialy XXI mezhdunarodnoi nauchno-prakticheskoi konferentsii. Moscow, 2015, pp.41-46.

18. Nvizug-Bi L.K. Otsenka tekhnologicheskikh reshenii dlia razrabotki $\mathrm{i}$ osvoeniia mestorozhdeniia tiazheloi $\mathrm{i}$ bituminoznoi nefti $\mathrm{v}$ Nigerii [Estimation of technological solutions for the development and development of heavy and bituminous oil fields in Nigeria]. Nauchnyi zhurnal Kubanskogo gosudarstvennogo agrarnogo universiteta, 2016, no.120(06), pp.44-49.
19. Adegoke O.S. Geological guide to some Nigerian cretaceous - recent localities. 7th African Micropalaeontological Colloquim, Ile - Ife, 1976, p. 6.

20. Adegoke O.S. Tar sand project phase II - estimation of reserves, materials testing and chemical analysis. Geological Consultancy Units, University of Ife, Nigeria, 1976, p.10.

21. Gwynn J.W. Instrumental analysis of tars and their correlations in oil impregnated sand stone beds. Unitah and grand countries, Utah. Utah geological and mineral survey, special studies, 1971, pp.5-8.

22. JeJe L.K. Aspect of the geomorphology of Nigeria in geography of Nigeria development. - Ibadan, 1983, pp. 5-8.

23. Kadiri M.O. Further desmids from the Ikpoba reservoir: A comparison from elsewhere in Africa. Algological Studies, 1993, no.71, pp. 23-25.

24. Ajayi O. Quality of ground water in the Agbabu oil sands area of Ondo State, Nigeria. Journal of African Earth Sciences, 1998, vol.27, pp.299-305. DOI: 10.1016/S0899-5362(98)00064-5

25. Nvizug-Bi L.K. Ekonomicheskaia znachimost razrabotki, osvoeniia i dobychi bituma iz bituminoznogo peska $\mathrm{i}$ tiazheloi nefti $\mathrm{v}$ Nigerii [The economic significance of the development, development, and extraction of bitumen from bituminous sand and heavy oil in Nigeria]. Nauchnyi zhurnal Kubanskogo gosudarstvennogo agrarnogo universiteta, 2016, no.121 (07), pp.144-149.

26. Nvizug-Bi L.K., Savenok O.V. Analiz prirodnogeologicheskikh uslovii zaleganiia mestorozhdenii $\mathrm{s}$ trudnoizvlekaemymi zapasami na territorii Federativnoi Respubliki Nigerii [Analysis of the natural and geological conditions of the deposit of deposits with hard-to-recover reserves in the territory of the Federal Republic of Nigeria]. Evraziiskii nauchnyi zhurnal, 2015, no.12, pp.50-57.

27. Adegoke O.S. Geotechnical investigation of the ondo state bituminous sands, geology and reserves estimate. Geological Consultancy Unit, University of Ife. Ife, 1980, p. 257.

28. Adegoke O.S., Ibe F.C. The tarsands and heavy crude resources of Nigeria. Proceedings of 2nd Unitar conference. Caracas, 1982, pp.8-10.

29. Frazier N.A. et al. Production and processing of US Tar sands: An environmental assessment. Virginia, 1976, 266 p.

30. Andrew E.D. Modern NMR techniques for chemistry research. New York, Pergamon Press, 1987, 403 p.

31. Eriksson S., Lasic S., Topgaard D. Isotropic diffusion weighting in PGSE NMR by magnetic - angle spinning of q-vector. Journal of Magnetic Resonance, 2013, vol.226, pp.13-18. DOI: 10.1016/j.jmr.2012.10.015

32. Lee J.H., Okuno Y., Cavagnero S. Sensitivity enhancement in solution NMR: Emerging ideas and new frontiers. Journal of Magnetic Resonance, 2014, vol.241, iss.1, pp.18-31. DOI: 10.1016/j.jmr.2014.01.005

33. Krivdin L.B. Calculation of $15 \mathrm{~N}$ NMR chemical shifts: Recent advances and perspectives. Progress in Nuclear Magnetic Resonance Spectroscopy, 2017, vol.102103, pp.98-119. DOI: 10.1016/j.pnmrs.2017.08.001

34. Vugmeyster L., Ostrovsky D. Static solid - state $^{2} \mathrm{H}$ NMR methods in studies of protein side chain dynamics. Progress in Nuclear Magnetic Resonance Spectroscopy, 2017, vol.101, pp.1-17. DOI: 10.1016/j.pnmrs.2017.02.001

35. Pileio G. Singlet NMR methodology in two spin - 1/2 systems. Progress in Nuclear Magnetic 
Resonance Spectroscopy, 2017, vol.98-99, pp.1-19. DOI: $10.1016 /$ j.pnmrs.2016.11.002

36. Haouas M., Taulelle F., Martineau Ch. Recent advances in application of 27Al NMR spectroscopy to material science. Progress in Nuclear Magnetic Resonance Spectroscopy, 2016, vol.94-95, pp.11-36. DOI: 10.1016/j.pnmrs.2016.01.003

37. Martin R.W., Kelly J.E., Collier K.A. Spatial reorientation experiments for NMR of solids and partially oriented liquids. Progress in Nuclear Magnetic Resonance
Spectros-copy, 2015, vol.90-91, pp.92-122. DOI: 10.1016/j.pnmrs.2015.10.001

38. Johnson R.L., Schmidt-Rohr K. Quantitative solidstate ${ }^{13} \mathrm{C}$ NMR with signal enhancement by multiple cross polarization. Journal of Magnetic Resonance, 2014, vol.239, pp.44-49. DOI: 10.1016/j.jmr.2013.11.009

39. Washburn K.E., Birdwell J.E. Updated methodology for nuclear magnetic resonance characterization of shales. Journal of Magnetic Resonance, 2013, vol. 233, pp.17-28. DOI: 10.1016/j.jmr.2013.04.014

\section{Библиографический список}

1. Совершенствование системы разработки месторождений природного битума / Р.М. Абдулханров, P.М. Ахнуров, Р.М. Гареев [и др.] // Повышение нефтеотдачи пластов на поздней стадии разработки нефтяных месторождений и комплексное освоение высоковязких нефтей и природных битумов: материалы Междунар. науч.-практ. конф. - Казань, 2007. - С. 227-234.

2. Абрамзон А.А. Поверхностно-активные вещества: свойства и применение. - Изд. 2-е, перераб. и доп. Ленинград: Химия, 1981. - 303 с.

3. Антониади Д.Г. Научные основы разработки месторождений термическими методами. - М.: Недра, 1995. - 313 c.

4. Антониади Д.Г., Валуйский А.А., Гарушев А.Р. Состояние добычи нефти методами повышения нефтеизвлечения в общем объеме мировой добычи // Нефтяное хозяйство. - 1999. - № 1. - С. 16-23.

5. Adegoke O.S., Omotsola M., Coker S. The geology of the Nigerian tar sands // 5th UNITAR Conference. Caracas, 1991. - P. 369-385.

6. Adelu R., Fayose E.Development prospects for the bituminous deposits in Nigeria // 5th UNITAR Conference. - Caracas, 1991. - P. 509-515.

7. Recovery of bitumen from Nigerian tar sands - feed preparation and solvent extraction studies / B. Ademodi, O. Dewodu, T. Oshonowo [et al.] // 7th Miami International Conference on Alternative Energy Sources. Miami, 1985. - P. 2.

8. Adewusi V.A. Aspect of tar sands development in Nigeria // Energy Sources. - 1992. - Vol. 14. P. 305-315. DOI: 10.1080/00908319208908728.

9. Adesida A. Geology of the ore tar sands (maastrichtian - paleocene): MSc. Thesis, University of Ife. Ife, 1980. - P. 121.

10. Способ повышения эффективной добычи природных битумов / Р.М. Ахунов, Р.М. Абдулхаиров, Р.3. Гареев [и др.] // Техника и добычи нефти. - 2007. № 8. - C. 132-134.

11. Липаев А.А. Разработка месторождений тяжелых и природных битумов. - М. - Ижевск: Ин-т компьютерных исследований, 2013. - 484 с.

12. РД 39-0147001-742-92. Методика комплексной оценки качества вскрытия продуктивных пластов, заканчивания скважин и выбора рабочих жидкостей для повышения качества вскрытия пластов. Краснодар: Российская государственная нефтегазовая корпорация, ВНИИКРнефть, 1992. - 82 с.
13. Муслимов Р.Х., Мусин М.М., Мусин К.М. Опыт применения тепловых методов разработки на нефтяных месторождениях Татарстана. - Казань: Новое знание, 2000. - 225 с.

14. Технологические принципы разработки залежей аномально вязких нефтей и битумов / Л.М. Рузин, И.Ф. Чупров, О.А. Морозюк [и др.]. - М. - Ижевск: Ин-т компьютерных исследований, 2015. - 476 с.

15. Априорная оценка качества вскрытия пласта по данным экспериментальных исследований на натурных кернах / В.И. Яковенко, Н.Ю. Мойса, П.П. Овсянников [и др.] // Строительство нефтяных и газовых скважин на суше и на море. - 2010. - № 2. - С. 50-51.

16. Нвизуг-Би Л.К., Савенок О.В., Мойса Ю.Н. Классификация трудноизвлекаемых запасов на территории Федеративной Республики Нигерия // Наука, техника и технология. - 2015. - Т. 11 (17), № 2. - P. 18-21.

17. Нвизуг-Би Л.К., Савенок О.В. Трудноизвлекаемые запасы углеводородов, важные ресурсы на территории Федеративной Республики Нигерия // Современное состояние естественных и технических наук: материалы XXI Междунар. науч.-практ. конф. М., 2015. - C. 41-46.

18. Нвизуг-Би Л.К. Оценка технологических решений для разработки и освоения месторождения тяжелой и битуминозной нефти в Нигерии // Научный журнал Кубанского государственного аграрного университета. - 2016. - № 120(06). - С. 44-49.

19. Adegoke O.S. Geological guide to some Nigerian cretaceous - recent localities // 7th African Micropalaeontological Colloquim, Ile - Ife, 1976. - P. 6.

20. Adegoke O.S. Tar sand project phase II estimation of reserves, materials testing and chemical analysis / Geological Consultancy Units, University of Ife, Nigeria, 1976. - P. 10.

21. Gwynn J.W. Instrumental analysis of tars and their correlations in oil impregnated sand stone beds. Unitah and grand countries, Utah // Utah geological and mineral survey, special studies. -1971 . - P. 5-8.

22. JeJe L.K. Aspect of the geomorphology of Nigeria in geography of Nigeria development. - Ibadan, 1983. - P. 5-8.

23. Kadiri M.O. Further desmids from the Ikpoba reservoir: A comparison from elsewhere in Africa // Algological Studies. - 1993. - № 71. - P.23 - 35.

24. Ajayi O. Quality of ground water in the Agbabu oil sands area of Ondo State, Nigeria // Journal of African 
Earth Sciences. - 1998. - Vol. 27. - P. 299-305. DOI: 10.1016/S0899-5362(98)00064-5.

25. Нвизуг-Би Л.К. Экономическая значимость разработки, освоения и добычи битума из битуминозного песка и тяжелой нефти в Нигерии // Научный журнал Кубанского государственного аграрного университета. - 2016. - № 121 (07). P. 144-149.

26. Нвизуг-Би Л.К., Савенок О.В. Анализ природногеологических условий залегания месторождений с трудноизвлекаемыми запасами на территории Федеративной Республики Нигерия /// Евразийский научный журнал.- 2015. - № 12. - Р. 50-57.

27. Adegoke O.S. Geotechnical investigation of the ondo state bituminous sands, geology and reserves estimate / Geological Consultancy Unit, University of Ife. Ife, 1980. - P. 257.

28. Adegoke O.S., Ibe F.C. The tarsands and heavy crude resources of Nigeria // Proceedings of 2nd Unitar conference. - Caracas, 1982. - P. 8-10.

29. Production and processing of US Tar sands: An environmental assessment / N.A. Frazier [et al.]. Virginia, 1976. - P. 266.

30. Andrew E.D. Modern NMR techniques for chemistry research. - New York: Pergamon Press, 1987. - 403p.

31. Eriksson S., Lasic S., Topgaard D. Isotropic diffusion weighting in PGSE NMR by magnetic angle spinning of q-vector // Journal of Magnetic Resonance. - 2013. - Vol. 226. - P. 13-18. DOI: 10.1016/j.jmr.2012.10.015

32. Lee J.H., Okuno Y., Cavagnero S. Sensitivity enhancement in solution NMR: Emerging ideas and new frontiers // Journal of Magnetic Resonance. - 2014. Vol. 241, iss. 1. - P. 18-31. DOI: 10.1016/j.jmr.2014.01.005

33. Krivdin L.B. Calculation of $15 \mathrm{~N}$ NMR chemical shifts: Recent advances and perspectives // Progress in Nuclear Magnetic Resonance Spectroscopy. - 2017. Vol. 102-103. - P. 98-119. DOI: 10.1016/j.pnmrs.2017.08.001

34. Vugmeyster L., Ostrovsky D. Static solid - state ${ }^{2} \mathrm{H}$ NMR methods in studies of protein side chain dynamics // Progress in Nuclear Magnetic Resonance Spectroscopy. - 2017. - Vol. 101. - P. 1-17. DOI: 10.1016/j.pnmrs.2017.02.001

35. Pileio G. Singlet NMR methodology in two spin - 1/2 systems// Progress in Nuclear Magnetic Resonance Spectroscopy. - 2017. - Vol. 98-99. - P. 1-19. DOI: $10.1016 /$ j.pnmrs.2016.11.002

36. Haouas M., Taulelle F., Martineau Ch. Recent advances in application of 27Al NMR spectroscopy to material science // Progress in Nuclear Magnetic Resonance Spectroscopy. - 2016. - Vol. 94-95. P. 11-36. DOI: 10.1016/j.pnmrs.2016.01.003

37. Martin R.W., Kelly J.E., Collier K.A. Spatial reorientation experiments for NMR of solids and partially oriented liquids // Progress in Nuclear Magnetic Resonance Spectroscopy. - 2015. - Vol. 90-91. P. 92-122. DOI: 10.1016/j.pnmrs.2015.10.001

38. Johnson R.L., Schmidt-Rohr K. Quantitative solidstate ${ }^{13} \mathrm{C}$ NMR with signal enhancement by multiple cross polarization // Journal of Magnetic Resonance. - 2014. Vol. 239. - P. 44-49. DOI: 10.1016/j.jmr.2013.11.009

39. Washburn K.E., Birdwell J.E. Updated methodlogy for nuclear magnetic resonance characterization of shales // Journal of Magnetic Resonance. - 2013. Vol. 233. - P. 17-28. DOI: 10.1016/j.jmr.2013.04.014

Please cite this article in English as:

Nwizug-Bee L.K., Savenok O.V., Moysa Yu.N. Application of nuclear magnetic resonance to study bituminous oil in the south western Nigeria. Perm Journal of Petroleum and Mining Engineering, 2018, vol.17, no.2, pp.115-122. DOI: $10.15593 / 2224-9923 / 2018.2 .2$

Просьба ссылаться на эту статью в русскоязычных источниках следующим образом:

Нвизуг-Би Л.К., Савенок О.В., Мойса Ю.Н. Применение ядерно-магнитного резонанса для изучения битуминозной нефти на юго-западе Нигерии // Вестник Пермского национального исследовательского политехнического университета. Геология. Нефтегазовое и горное дело. - 2018. - Т.17, №2. - C.115-122. DOI: $10.15593 / 2224-9923 / 2018.2 .2$ 